\title{
Survey of infection in orthopedic postoperative and their causative agents: a prospective study
}

\author{
Gabriel de Deus Vieira ${ }^{1 *}$, Hallan Rodrigues Mendonça² ${ }^{2}$, Thaianne da Cunha Alves ${ }^{1}$, Danilo Fernandes de Oliveira Araújo${ }^{1}$, \\ Mauro lopes da Silveira Filho ${ }^{1}$, André Pastuczenko dos Santos Rodrigues de Freitas ${ }^{3}$, Flávia Bressan³, \\ Renato de Figueiredo Radaeli², Camila Maciel de Sousa ${ }^{4}$ \\ ${ }^{1}$ Medical Student - Intern in the Microbiology laboratory, Faculdade São Lucas, Porto Velho, RO, Brazil \\ ${ }^{2}$ Orthopedist - Staff, Orthopedics and Traumatology Service, Hospital de Base Dr. Ary Pinheiro, Porto Velho, RO, Brazil \\ ${ }^{3}$ Resident in Orthopedics and Traumatology - Orthopedics and Traumatology Service, Hospital de Base Dr. Ary Pinheiro, Porto Velho, RO, Brazil \\ ${ }^{4}$ Biologist - Lecturer at the Medical Department, Faculdade São Lucas, Porto Velho, RO, Brazil
}

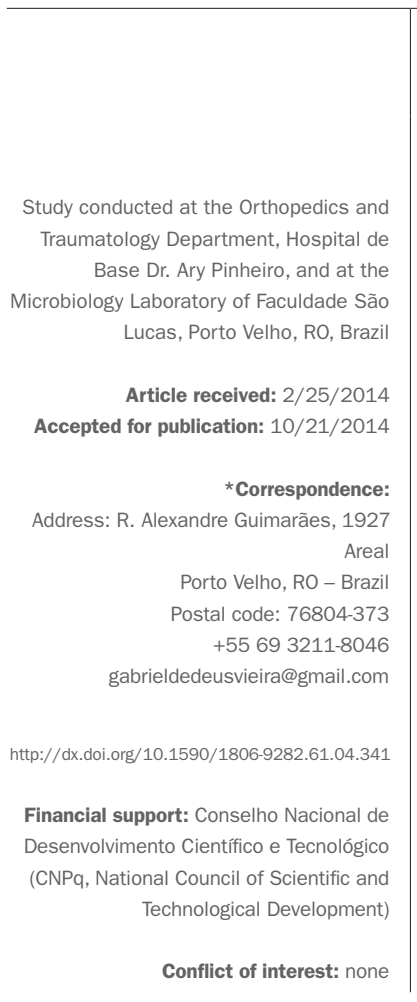

\section{INTRODUCTION}

Infections in orthopedic surgeries not only prolong the length of stay in two weeks on average, but also increase morbidity, double the hospitalization rates and triple the financial costs of the patient. ${ }^{1,2}$ Infections in the surgical site are the third most common cause of infection in surgical patients. ${ }^{3}$

Some factors such as advanced age, concomitant infection elsewhere in the body, use of systemic steroids, smoking, drinking and transfusion of certain blood products also increase the risk of infection. ${ }^{4,5}$ With regard to the pathogen, the degree of infection depends on its virulence, the number of infecting microorganisms, site where the infection will progress, the patient's defense mechanisms, and the presence of factors leading to the patient's immunosuppression. ${ }^{6}$
Objective: to evaluate the cases of wound infections in orthopedic postoperative period.

Methods: postoperative patients who developed infection during the period from November 2012 to November 2013 were studied. Secretions were collected during surgery using sterile swabs, and sent for microbiological analysis.

Results: during the period analyzed, 38 surgical procedures progressed to infection. The type of surgery presenting the largest number of infections was osteosynthesis, in 36 (94.7\%) patients. Among the materials used, 18 (36\%) surgeries that used external fixator were infected, and 17 (34\%) using plate. The species of bacteria that caused the largest number of infections were Staphylococcus aureus, infecting 16 (43.9\%) patients, followed by Acinetobacter baumannii, which infected four (10.5\%) patients. Regarding the resistance profile of Gram-positive strains to antibiotics, $100 \%$ of Staphylococcus aureus strains were susceptible to vancomycin and $31.3 \%$, to ceftriaxone. As for the Gram-negative bacteria, 100\% of Acinetobacter baumannii strains were resistant to ceftriaxone, gentamicin and imipenem.

Conclusion: infection control in the postoperative period is necessary, using antibiotics correctly and consciously, avoiding resistance of bacterial agents.

Keywords: surgical wound infection, orthopedics, hospital infection. 


\section{Methods}

\section{Study site and population}

The authors conducted a prospective study in which postoperative orthopedic surgery patients showing signs and symptoms indicative of infection were analyzed during the period from November 2012 to November 2013, at the Orthopedics and Traumatology Service, Hospital de Base Dr. Ary Pinheiro in Porto Velho, state of Rondônia.

\section{Samples}

The collection of samples was performed by resident physicians supervised by the staff of residency in Orthopedics and Traumatology, being performed through direct collection from the surgical site's necrotic material, purulent discharge, samples of bone tissue and osteosynthesis collected with the aid of swabs into Stuart medium. Asepsis and antisepsis of the site of material collection were performed with degerming chlorhexidine and gauze soaked in chlorhexidine. Then the samples were labeled and sent to the Microbiology Laboratory at Faculdade São Lucas, where culture of the samples, identification of bacteria and susceptibility testing were performed.

\section{Study variables}

The authors identified gender, age, type of surgery, surgical material, affected bone, antibiotic used empirically (administered until the results of culture and sensitivity were received) and associated comorbidities. The bacteria causing the infection and their antimicrobial resistance profile were also identified.

\section{Ethical aspects}

In cases diagnosed, and after the free and informed consent form was signed by the patient or legal guardian, the patient's medical record was analyzed with the assistance of one of the doctors responsible for the case and subsequently biological materials were collected in the operating room. This study was conducted after approval by the Ethics in Research Committee of Faculdade São Lucas.

\section{ResULTS}

985 orthopedic surgeries were performed during the study period. Of these, 38 (3.9\%) surgical procedures progressed to infection, requiring cleaning and collection of secretions derived from the source of infection. 26 (68.4\%) of these patients were male, and $12(31.6 \%)$ female. The age range most affected was between $20-39$ years (50\%). The average time between surgery and the search for care due to signs of infection was 21 days. The types of surgery presenting the greatest number of infections were fracture osteosyn- thesis, in $36(94.7 \%)$ patients, and arthroplasty in $2(5.3 \%)$ patients. The average time spent in surgery, which subsequently developed infection, was 1 hour and 40 minutes. The average number of people in the operating room for surgery that became infected was 4.7 persons, including orthopedic surgeons, resident physicians and circulating staff. Air conditioning was on during all surgical procedures that became infected. Regarding surgical material, external fixator was used in 18 (36\%) surgeries that became infected, and plate was used in 17 (34\%) surgeries. As for comorbidities, 9 (23.7\%) patients had high blood pressure $(\mathrm{BPH})$ and $7(18.4 \%)$ had diabetes. 8 (21.1\%) patients progressed to osteomyelitis (Table 1 ).

\begin{tabular}{|c|c|c|}
\hline Variables & $\mathbf{n}$ & $\%$ \\
\hline \multicolumn{3}{|l|}{ Age range } \\
\hline $0-19$ & 3 & 7.9 \\
\hline $20-39$ & 19 & 50 \\
\hline $40-59$ & 11 & 28.9 \\
\hline$>60$ & 5 & 13.2 \\
\hline
\end{tabular}

\begin{tabular}{lll}
\hline Type of surgery & & \\
\hline Osteosynthesis & 36 & 94.7 \\
\hline Arthroplasty & 2 & 5.3 \\
\hline Material & & \\
\hline External fixator & 18 & 36 \\
\hline Plate & 17 & 34 \\
\hline Kirschner wire & 6 & 12 \\
\hline Intramedullary rod & 3 & 6 \\
\hline Screw & 2 & 4 \\
\hline Ethibond suture & 2 & 4 \\
\hline Hip prosthesis & 2 & 4 \\
\hline
\end{tabular}

\begin{tabular}{lll}
\hline Comorbidities & & \\
\hline Arterial high blood pressure & 9 & 23.7 \\
\hline Diabetes & 7 & 18.4 \\
\hline Kidney failure & 1 & 2.6 \\
\hline Hanseniasis & 1 & 2.6 \\
\hline Osteomyelitis & & \\
\hline Yes & 8 & 21.1 \\
\hline No & 21 & 55.3 \\
\hline Indicative & 9 & 23.6
\end{tabular}

Regarding the infected bone, the femur and the tibia had a higher prevalence, 15 (35\%) patients each bone; followed by the fibula, $3(7 \%)$ patients; hip, metatarsus and talus, 2 
(5\%) patients each bone; and patella, clavicle, phalanx and soft tissues, 1 (2\%) patient each. Among the antibiotics used empirically, cephalothin was used in 15 (39.5\%) patients; 12 (31.6\%) patients were treated with ciprofloxacin; 8 (21.1\%) with clindamycin; 3 (7.9\%) were treated with vancomycin; 2 (5.2\%), with cefepime; 2 (5.2\%), with gentamicin; 1 (2.6\%), with ceftriaxone; 1 (2.6\%), with amikacin; 1 (2.6\%), with ceftazidime; and $1(2.6 \%)$, with cefazolin.

The bacterial species that caused the largest number of infections was Staphylococcus aureus, infecting 16 (42.1\%) patients, followed by Acinetobacter baumannii and Staphylococcus epidermidis, which infected 4 (12.5\%) patients each, and Pseudomonas aeruginosa and Klebsiella pneumoniae, which infected $3(7.9 \%)$ patients each (Figure 1).

In relation to the resistance profile of Gram-positive strains to the antibiotics, $31.3 \%$ of the Staphylococcus aureus strains were susceptible to ceftriaxone, $50 \%$ to gentamicin and $100 \%$ to vancomycin. As for Gram-negative strains, $50 \%$ of the Acinetobacter baumannii strains were susceptible to sulfamethoxazole/trimethoprim and $100 \%$ were resistant to ceftriaxone, imipenem e ciprofloxacin; in the case of strains of Psendomonas aeruginosa, $66.6 \%$ were susceptible to imipenem and $66.6 \%$ were susceptible to sulfamethoxazole/trimethoprim; $33.4 \%$ of the strains of Klebsiella pneumoniae were susceptible to ceftriaxone, $100 \%$ to imipenem and $0 \%$ to ciprofloxacin (Table 2).

\section{Discussion}

In order to achieve a good treatment for infections in postsurgical setting, extensive surgical debridement must be done ${ }^{10}$ as well as proper antibiotic prophylaxis and correct definitive antibiotic therapy in a conscious manner. ${ }^{11}$ Infectious syndromes that developed within one year of surgery are considered nosocomial infections and should be treated empirically until culture results are ready. During the surgery, antibiotic prophylaxis is recommended in order to prevent infections due to surgical manipulation. According to D'Elia et al., ${ }^{12}$ superficial infections should receive aggressive antibiotic therapy, avoiding progression to deep infection, that can lead to sepsis. Prophylaxis especially directed to Staphylococcus aureus is recommended due to its high prevalence in infections. ${ }^{13,14}$ Typically, first and second generation cephalosporins are used. ${ }^{15,16}$ In this study, the authors noted that the antibiotic most commonly used for prophylaxis was cephalothin; a first generation cephalosporin.

According to Mangram et al., ${ }^{4}$ the main risk factors for the development of postsurgical infections are malnutrition, prolonged hospital length of stay, older age, previous surgery, long duration of surgery, and obesity. In this study, the increased number of the following comorbidities was found among patients who developed infection: high blood pressure (23.7\%) and diabetes mel-

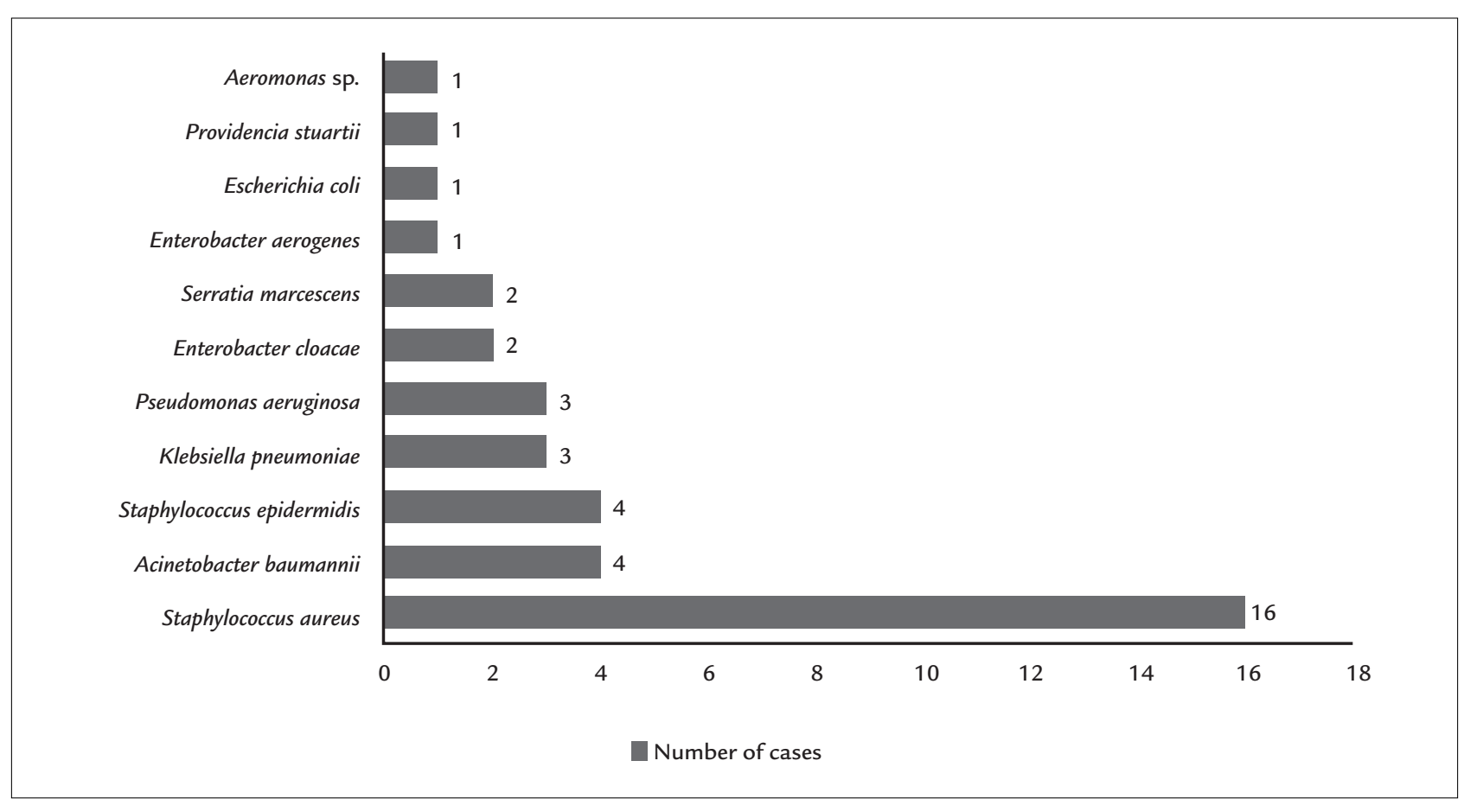

FIGURE 1 Number of cases of infection according to the bacteria. 
TABLE 2 Sensitivity percentage and antimicrobial resistance of bacterial strains isolated from infection after orthopedic surgery.

Antibiotic drug (\%)

\begin{tabular}{|c|c|c|c|c|c|c|c|c|c|c|c|c|c|c|c|c|}
\hline \multirow[t]{2}{*}{ Bacteria (n) } & \multicolumn{2}{|c|}{ Oxacillin } & \multicolumn{2}{|c|}{$\begin{array}{l}\text { Ampicillin/ } \\
\text { Sulbactam }\end{array}$} & \multicolumn{2}{|c|}{ Ceftriaxone } & \multicolumn{2}{|c|}{ Gentamicin } & \multicolumn{2}{|c|}{$\begin{array}{l}\text { Sulfamethoxazole/ } \\
\text { Trimethoprim }\end{array}$} & \multicolumn{2}{|c|}{ Vancomycin } & \multicolumn{2}{|c|}{ Imipenem } & \multicolumn{2}{|c|}{ Ciprofloxacin } \\
\hline & $\mathbf{S}$ & $\mathbf{R}$ & $\mathrm{S}$ & $\mathbf{R}$ & S & $\mathbf{R}$ & $\mathbf{S}$ & $\mathbf{R}$ & $\mathbf{S}$ & $\mathbf{R}$ & $S$ & $\mathbf{R}$ & $\mathbf{S}$ & $\mathbf{R}$ & $\mathbf{S}$ & $\mathbf{R}$ \\
\hline $\begin{array}{l}\text { Staphylococcus } \\
\text { aureus (16) }\end{array}$ & 37.5 & 62.5 & 6.2 & 93.8 & 31.3 & 68.7 & 50 & 50 & 68.8 & 32.2 & 100 & 0 & $\mathrm{~N}$ & $\mathrm{~N}$ & 6.2 & 93.8 \\
\hline $\begin{array}{l}\text { Staphylococcus } \\
\text { epidermidis (4) }\end{array}$ & 50 & 50 & 75 & 25 & 75 & 25 & 25 & 75 & 100 & 0 & 100 & 0 & $\mathrm{~N}$ & $\mathrm{~N}$ & 0 & 100 \\
\hline $\begin{array}{l}\text { Acinetobacter } \\
\text { baumannii (4) }\end{array}$ & $\mathrm{N}$ & $\mathrm{N}$ & 0 & 100 & 0 & 100 & 0 & 100 & 50 & 50 & 0 & 100 & 0 & 100 & 0 & 100 \\
\hline $\begin{array}{l}\text { Pseudomonas } \\
\text { aeruginosa ( } 3 \text { ) }\end{array}$ & $\mathrm{N}$ & $\mathrm{N}$ & 0 & 100 & 0 & 100 & 33.4 & 66.6 & 0 & 100 & $\mathrm{~N}$ & 0 & 66.6 & 33.4 & 33.4 & 66.6 \\
\hline $\begin{array}{l}\text { Klebsiella } \\
\text { pneumoniae (3) }\end{array}$ & $\mathrm{N}$ & $\mathrm{N}$ & 0 & 100 & 33.4 & 66.6 & 33.4 & 66.6 & 66.6 & 33.4 & $\mathrm{~N}$ & 0 & 100 & 0 & 0 & 100 \\
\hline $\begin{array}{l}\text { Enterobacter } \\
\text { cloacae (2) }\end{array}$ & $\mathrm{N}$ & $\mathrm{N}$ & 0 & 100 & 50 & 50 & 0 & 100 & 50 & 50 & $\mathrm{~N}$ & 0 & 100 & 0 & 50 & 50 \\
\hline $\begin{array}{l}\text { Serratia } \\
\text { marcescens (2) }\end{array}$ & $\mathrm{N}$ & $\mathrm{N}$ & 0 & 100 & 50 & 50 & 50 & 50 & 50 & 50 & $\mathrm{~N}$ & 0 & 100 & 0 & 0 & 100 \\
\hline $\begin{array}{l}\text { Enterobacter } \\
\text { aerogenes (1) }\end{array}$ & $\mathrm{N}$ & $\mathrm{N}$ & 0 & 100 & 50 & 50 & 0 & 100 & 0 & 100 & $\mathrm{~N}$ & 0 & 100 & 0 & 0 & 100 \\
\hline $\begin{array}{l}\text { Aeromonas sp. } \\
\text { (1) }\end{array}$ & $\mathrm{N}$ & $\mathrm{N}$ & 0 & 100 & 100 & 0 & 100 & 0 & 100 & 0 & $\mathrm{~N}$ & 0 & 100 & 0 & 100 & 0 \\
\hline $\begin{array}{l}\text { Providencia } \\
\text { stuartii (1) }\end{array}$ & $\mathrm{N}$ & $\mathrm{N}$ & 0 & 100 & 0 & 100 & 0 & 100 & 100 & 0 & $\mathrm{~N}$ & 0 & 100 & 0 & 0 & 100 \\
\hline $\begin{array}{l}\text { Escherichia } \\
\text { coli }(1)\end{array}$ & $\mathrm{N}$ & $\mathrm{N}$ & 100 & 0 & 100 & 0 & 100 & 0 & 100 & 0 & $\mathrm{~N}$ & 0 & 100 & 0 & 100 & 0 \\
\hline
\end{tabular}

$\mathrm{S}=$ sensitive; $\mathrm{R}=$ resistant; $\mathrm{N}=$ not tested.

litus (18.4\%). Subjects presenting chronic conditions have a greater risk of developing infections, on account of decreased physical and immunological resistance.

Ercole et al., ${ }^{3}$ in a study about infection in orthopedic surgical site, found that 50 surgeries that progressed to infection had durations shorter than 120 minutes, while 13 took more than 120 minutes. They also showed that the average time between surgery and infection was 95.8 days and, in terms of gender, $57.7 \%$ of patients were women. In this study, the average time spent in surgery ( 1 hour and 40 minutes) and the average time between surgery and infection (21 days) were shorter and, in relation to gender, men were more prevalent. According to Khan et al., ${ }^{17}$ surgeries with duration longer than 120 minutes have a risk factor for infection due to greater exposure of tissues and fatigue of the team, facilitating technical failures.

Villa et al., ${ }^{18}$ in a study on infection in open fractures, found that the bones more often affected were tibia (32\%) and femur (26.7\%). The authors also showed higher prev- alence in the male population and in the age range between 30 and 59 years. This study also showed a higher prevalence of involvement of these bones in the male population and the age group of 20-39 years.

In this study, the authors noticed that the air conditioning was present in all surgeries that were infected. Ventilation aims to maintain a pleasant operating room environment, but the lack of maintenance and dust accumulation can turn the appliance into a source of various pathogens. ${ }^{4,19,20}$

Postoperative progression of infected wound to osteomyelitis is an important and feared complication, due to the risk of functional changes in the ends of fractured bones. ${ }^{21}$ In the present study, the authors observed that 8 (21.1\%) surgeries progressed to osteomyelitis postoperatively.

Villa et al. ${ }^{18}$ found that ciprofloxacin, clindamycin and cephalosporin had been used as empirical antibiotics in $33.3 \%$ of the patients who progressed to infection. In their study, the antibiotics of choice for empirical treatment of 
most patients were the same ones used in this study. Müller et al. ${ }^{15}$ evaluated 26 cases of infection in open fractures and found that, among the Gram-positive bacteria, coagulase-negative Staphylococci were the most prevalent, while Acinetobacter sp. was the most prevalent among the Gramnegative. Silva et al., ${ }^{22}$ in their study on infection in fractures of the lower limbs, noticed that Staphylococcus aure$u s$ was present in all cases, except one in which the culture was positive for Pseudomonas aeruginosa. In this study, a higher prevalence of Staphylococcus aureus (42.1\%) was also observed among Gram-positive bacteria, followed by Staphylococcus epidermidis (10.5\%). Among the gram-negative, Acinetobacter baumannii was the most prevalent (10.5\%).

Graça et al., ${ }^{20}$ in a study on orthopedic surgery infection in a university hospital, found that $30.7 \%$ of the bacteria causing infections were Staphylococcus aureus, $17.3 \%$ were Psendomonas aeruginosa, 7.6\% Klebsiella sp. and 5.7\% Enterobacter sp. In the antibiogram, $81.2 \%$ of the strains of Staphylococcus aureus were sensitive to oxacillin and cephalothin, while $22.2 \%$ of the strains of Psendomonas aeruginosa were susceptible to gentamicin, and $75 \%$ of the strains of Klebsiella sp. were susceptible to gentamicin. In this study, Pseudomonas aeruginosa were present in 3 (7.9\%) patients. They also found that most of the strains of Staphylococcus aureus were resistant to oxacillin; while $66.6 \%$ of the strains of Pseudomonas aeruginosa were resistant to gentamicin, and one third of the strains of Klebsiella pneumoniae were susceptible to gentamicin.

According to Mortazavi et al., ${ }^{23} 1$ to $5 \%$ of the prostheses used in orthopedic surgeries become infected. Lima et al. ${ }^{24}$ noticed that, among the etiologic agents found in hip prosthesis infections, the most important are Pseudomonas aeruginosa, coagulase-negative Staphylococci and Acinetobacter calcoaceticus. According to the authors, the main risk factor was increased surgical time. In this study, in the $2(5.3 \%)$ cases of hip prosthesis infection, two types of bacteria were found: Enterobacter cloacae and Staphylococcus aureus. The sources of infection in prostheses are mainly related to lower limb ulcers, pneumonia, urinary foci and skin abscesses. ${ }^{25}$

\section{Conclusion}

The surgical procedure with the highest number of infections was the osteosynthesis, and materials that had the highest prevalence of infections were the external fixator and the plate. Among the Gram-positive bacteria, Staphylococcus aureus was the most prevalent, while the most prevalent Gram-negative was Acinetobacter baumannii. Infections in surgical site are worrying events, due to their severity and high cost to public coffers, so it is essential to prevent infections and, in case this is not enough, to establish a rapid diagnosis and proper conduct for treatment in order to prevent progression.

\section{Resumo}

Avaliação de infecção no pós-operatório ortopédico e seus agentes causadores: estudo prospectivo

Objetivo: avaliar os casos de feridas infectadas em pós-operatório ortopédico.

Métodos: foram estudados pacientes de pós-operatório que evoluíram com processo infeccioso, durante o período de novembro de 2012 a novembro de 2013. Foi realizada coleta intraoperatória de secreções com o auxílio de swabs estéreis, e o material foi encaminhado para análise microbiológica.

Resultados: durante o período analisado, 38 procedimentos cirúrgicos evoluíram para processo infeccioso. O tipo de cirurgia que apresentou o maior número de infecções foi a osteossíntese, em 36 (94,7\%) pacientes. Em relação ao material utilizado, 18 (36\%) cirurgias que empregaram fixador externo e 17 (34 \%) que fizeram uso de placa se infectaram. A bactéria que causou o maior número de infecções foi a Staphylococcus aureus, acometendo 16 (43,9\%) pacientes, seguida pela Acinetobacter baumannii, que acometeu $4(10,5 \%)$ pacientes. Em relação ao perfil de resistência das cepas Gram-positivas aos antibióticos, 100\% das cepas de Staphylococcus aureus foram sensíveis à vancomicina, e 31,3\%, à ceftriaxona. Quanto às bactérias Gram-negativas, 100\% das cepas de Acinetobacter baumannii apresentaram resistência a ceftriaxona, gentamicina e imipenem.

Conclusão: o controle de infecções em pós-operatório se faz necessário, utilizando antibióticos de forma correta e consciente, evitando a resistência aos agentes bacterianos.

Palavras-chave: infecção da ferida operatória, ortopedia, infecção hospitalar.

\section{REFERENCES}

1. Barbos M, Portigliatti BM, Pecoraro S, Picco W, Veglio V. Decolonization of orthopedic surgical team S. aureus carriers: impact on surgical-site infections. J Orthopaed Traumatol. 2010; 11:47-9.

2. Rabhae GN, Ribeiro Filho N, Fernandes AT. Infecção do sítio cirúrgico. In: Fernandes AT (ed.). Infecção hospitalar e suas interfaces na área da saúde. São Paulo: Atheneu, 2000. p.479-505.

3. Ercole FF, Chianca, TCM, Duarte D, Starling CEF, Carneiro M. Surgical site infection in patients submitted to orthopedic surgery: The NNIS Risk Index and Risk Prediction. Rev Latinoam Enferm. 2011; 19(2):269-76.

4. Mangram AJ, Horan TC, Pearson ML, Silver LC, Jarvis WR. Guideline for prevention of surgical site infection. Infect Control Hosp Epidemiol. 1999; 20(4):250-78.

5. Stracieri LDS. Cuidados e complicações pós-operatórias. Medicina (Ribeirão Preto) 2008 ; 41(4):465-8. 
6. Rocha JJR. Infecção em cirurgia e cirurgia das infecções. Medicina (Ribeirão Preto). 2008; 41(4):487-90.

7. Cabrita HB, Croci AT, Camargo OP, Lima AL. Prospective study of the treatment of infected hip arthroplasties with or without the use of an antibiotic-loaded cement spacer. Clinics (Sao Paulo). 2007; 62(2):99-108.

8. Brennan SA, Walls RJ, Smyth E, Mulla TA, O'Byrne J. Tourniquets and exsanguinators: a potential source of infection in the orthopedic operating theater? Acta Orthop. 2009; 80(2):251-5.

9. Santos MLG, Teixeira R, Augusto Filho D. Surgical site infections in adults patients undergoing of clean and contaminated surgeries at a university brazilian hospital. Arq Gastroenterol. 2010; 47(4):10-6.

10. Del Pozo JL, Patel R. Clinical practice. Infection associated with prosthetic joints. N Engl J Med. 2009; 361(8):787-94.

11. Carneiro M, Ferraz T, Bueno T, Koch BE, Foresti CF, Lena VF, et al. O uso de antimicrobianos em um hospital de ensino: uma breve avaliação. Rev Assoc Med Bras. 2011; 57(4):421-4.

12. D’Elia CO, Santos ALG, Leonhardt MCL, Lima ALLM, Pécora JR, Camanho GLL. Tratamento das infecções pós-artroplastia total de joelho: resultados com 2 anos de seguimento. Acta Ortop Bras. 2007; 15(3):158-62.

13. Frommelt L. Principles of systemic antimicrobial therapy in foreign material as-sociated infection in bone tissue, with special focus on periprosthetic infection. Injury. 2006; 37(Suppl 2):87-94.

14. Lima ALLM, Oliveira PRSD. Atualização em infecções em próteses articulares. Rev Bras Ortop. 2010; 45(6):520-3

15. Müller SS, Sadenberg T, Pereira GJC, Sadatsune T, Kimura EE, Novelli Filho JLV. Estudo epidemiológico, clínico e microbiológico prospectivo de pacientes portadores de fraturas expostas atendidos em hospital universitário. Acta Ortop Bras. 2003; 11(3):158-69.
16. Secretaria de Estado da Saúde. Coordenadoria de controle de doenças - SSD. Infecção em sítio cirúrgico. São Paulo, 2005.

17. Khan MS, Rehman S, Ali MA, Sultan B, Sultan S. Infection in orthopedic implant surgery, its risk factors and outcome. J Ayub Med Coll Abbottabad. 2008; 20(1):23-5.

18. Villa PEA, Nunes TR, Gonçalves FP, Martins JS, Lemos GSP, Moraes FB. Avaliação clínica de pacientes com osteomielite crônica após fraturas expostas tratados no Hospital de Urgências de Goiânia, Goiás. Rev Bras Ortop. 2013; 48(1):22-8.

19. Lima ALM, Zumiotti AV, Uip DE, Silva SJ. Fatores preditivos de infecção em pacientes com fraturas expostas nos membros inferiores. Acta Ortop Bras. 2004; 12(1):23-39.

20. Graça R, Giordano M, Castro E. Infecção pós-operatória: estudo de cirurgias ortopédicas realizadas no Hospital Universitário Pedro Ernesto-UERJ em um ano. Rev Bras Ortop. 1997; 32(1):1-5.

21. Kutscha-Lissberg F, Hebler U, Kälicke T, Arens S. Principles of surgical therapy concepts for postoperative and chronic osteomyelitis. Orthopade. 2004; 33(4):439-54

22. Silva AGP, Silva FBA, Santos ALG, Malheiros CAM, Sakaki MH, Umiotti AZ. Infecção pós-estabilização intramedular das fraturas diafisárias dos membros inferiores protocolo de tratamento. Acta Ortop Bras. 2008; 16(5):266-9.

23. Mortazavi S, Schwartzenberger J, Austin M Purtill J, Parvizi J. Revision total knee arthroplasty infection. Clin Orthop Relat Res. 2010; (468):2052-9.

24. Lima ALLM, Barone AA. Infecções hospitalares em 46 pacientes submetidos a artroplastia total do quadril. Acta Ortop Bras. 2001; 9(1):36-40.

25. Donovan TL, Gordon RO and Nagel DA. Urinary infections in total hip arthroplasty. J Bone Joint Surg. 1976; 58(8):1134-7. 